\title{
What do Local People Know About Amazonian Manatees? Traditional Ecological Knowledge of Trichechus inunguis in the Oil Province of Urucu, AM, Brazil
}

\author{
André M. Franzini ${ }^{1,2}$, D. Nataly Castelblanco-Martínez ${ }^{2,3 *}$, \\ Fernando C. W. Rosas ${ }^{2}$ \& Vera M. F. da Silva ${ }^{2}$
}

\author{
${ }^{1}$ Programa de Pós-graduação em Ciências do Ambiente e Sustentabilidade na Amazônia, \\ Universidade Federal do Amazonas - UFAM, Manaus, AM, Brasil \\ ${ }^{2}$ Laboratório de Mamíferos Aquáticos, Instituto Nacional de Pesquisas da Amazônia - INPA, Manaus, AM, Brasil \\ ${ }^{3}$ Oceanic Society, Blackbird Field Station, Turneffe, Belize
}

\begin{abstract}
During 2005-2007, a series of interviews were carried out with the riverside populations of the Oil Province of Urucu (AM, Brasil). The main goal of this work was to characterize the knowledge of the inhabitants of this area regarding the Amazonian manatee (Trichechus inunguis) (listed as Vulnerable on the IUCN Red List). Interviews were conducted with 74 local inhabitants from 33 communities. Between 2004 and 2007, 20 poached or entangled Amazonian manatees were reported in the area. Poaching with harpoon is the principal cause of mortality, but manatees are also incidentally caught in fishing nets. Interviewers described details of manatee hunting techniques in the area. The trade of manatee meat, although currently forbidden by Brazilian laws, still occurs in the area. Data obtained from the interviews suggest a dietary preference of the manatee for at least 29 species of aquatic and semi-aquatic plants. The interviewed fishermen showed a sound knowledge of Amazonian manatee biology and behavior. This information may be important to assist future conservation plans in the Amazon.
\end{abstract}

Key words: Traditional Ecological Knowledge, Hunting, Amazon, Sirenia, Diet.

\section{Introduction}

Human activity and expansion in the Amazon region has exerted pressure on the Amazonian manatee, Trichechus inunguis, resulting in a reduction in the number of individuals (Rosas 1994). T. inunguis is listed as 'Vulnerable' to extinction by the International Union for Conservation of Nature (Marmontel 2008). The study of wild Amazonian manatees is particularly complicated, due to their cryptic behavior, low population density, and complex habitats. Traditional Ecological Knowledge (TEK), a culturally constructed knowledge that is passed through generations (Costa \& Nunez 2011), can be considered an excellent source of information about elusive species, regarding distribution, migration, feeding habits and reproduction. Therefore, information gathered from the local people can be used as a starting point for future scientific research.

This research aimed at assessing the conservation status of the manatee in the areas influenced by oil activities in

\footnotetext{
*Send correspondence to: D. Nataly Castelblanco-Martínez Laboratório de Mamíferos Aquáticos, Instituto Nacional de Pesquisas da Amazônia, Av. André Araújo, 2936, Petrópolis, CEP 69067-375, Manaus, AM, Brasil

E-mail: castelblanco.nataly@gmail.com
}

the Urucu Oil Province, and at describing how the local people perceive the manatee from a biological point of view.

\section{Material and Methods}

The study was carried out in Urucu River basin, located in the area of influence of the Urucu Oil Province, Municipality of Coari, Amazonas State (Figure 1). The information was obtained through individual interviews with locals. This approach is the most widely-used data collection strategy in qualitative research, and assumes that if questions are formulated correctly, participants' expressions of their experiences will reflect their reality (Lambert \& Loiselle 2008). Therefore, we typically choose individual interviews to collect detailed accounts of participants' thoughts, attitudes, beliefs, and knowledge pertaining to the manatee. The three most relevant parameters of selection were: (i) experience in manatee hunting or any other direct contact with the species, (ii), years living in the area (age) (iii) community leadership. Regular visits to the communities were made in order to gain the trust of local residents, and thereby to obtain more confidentiality in the responses. 


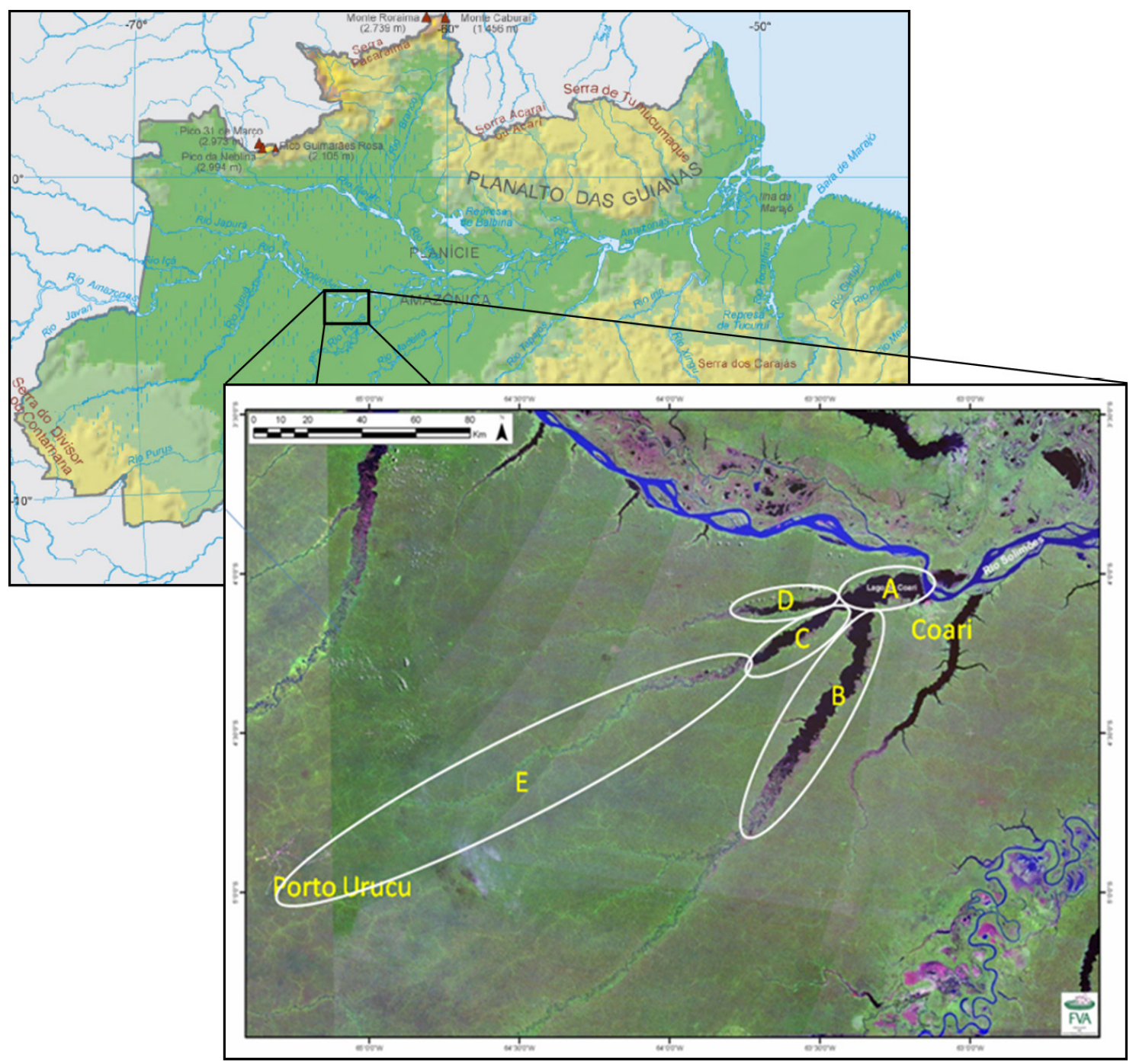

Figure 1. Area of Study. (A) Coari Lake; (B) Coari Grande Lake; (C) Urucu Lake; (D) Aruã Lake; (E) Urucu River (Image courtesy of Marcelo Moreira, FVA).

Interviews were conducted in 33 communities and 74 residents were interviewed. The semi-structured and in-depth interviews included open questions about manatee occurrence, general aspects of the biology and ecology of the species, and threats to the local manatee population. Once the information gathered during the interviews was organized, we determined probable presence spots. During the interviews, we also asked about the plants eaten by Amazonian manatees, in order to record dietary information. Aiming to collect and identify the plant species, three-weeks fieldtrips were carried out in the study area, guided by local fishermen. The excursions took place during low water season (Nov/2005), high water season (May/2005), and receding water season (Aug/2006). Plants believed by the locals as items of the manatee diet were collected and labeled with code and vernacular name, for subsequent taxonomic classification at the Instituto Nacional de Pesquisas da Amazonia (INPA). In order to determine the importance of each food item for the manatee, we used the percentage of mention (\%M), defined by (Equation 1):

$\%$ Mention of $\chi=\frac{(\text { Number of interviewers that mentionedx }) \times 100}{\text { Total of interviewers }}$

where $x$ is the plant species.

\section{Results}

Among the interviewees, $48.65 \%$ were dedicated to agriculture, $21.62 \%$ were fishermen and $8.11 \%$ hunters. However, it is widely known in the Amazon that the proportion of these activities varies according to the time of the year (Begossi et al. 1999; Harris 1998). None of them declared that they exclusively hunted manatee. All interviewees stated that they were familiar with identifying manatees in wild, by feeding areas, feces, or direct observations. The majority also admitted manatee meat consumption and/or manatee meat trading in the area. 
All the interviewed people showed high and accurate levels of knowledge of the Amazonian manatee biology. They were capable of describing accurately and in detail, several aspects of manatee morphology, behavior and ecology, revealing a strong intimacy with the species.

According to the local opinion, T. inunguis still inhabits the study area. With the help of the interviewees, 42 places were listed throughout the area where the presence of manatees has been detected by faeces, feeding tracks, mortality or sightings. Amazonian manatees are present in the Lakes Coari, Coari Grande, Urucu and Aruã, and also in Rivers Coari and Urucu (Table S1 in supplementary material available at abeco.org.br).

The consensus among interviewees was that T. inunguis has great hearing capabilities, fairly good olfactory senses and relatively poor vision. According to local fishermen, Amazonian manatees can be differentiated in one to four ethno-categories, depending on the coloration, size and social behavior (see Table 1 for details). For the respondents, $21.43 \%$ claimed that there is only one "class" of manatee, $42.86 \%$ recognized two ethno-categories manatee, $21.43 \%$ recognized four ethno-categories, and $14.28 \%$ did not know. In regard to the social behavior, most respondents (54.54\%) explained that manatees live in groups of 3 to 10 individuals, $18.18 \%$ think that the animals usually live alone or in couples, and $27.28 \%$ mentioned that they have seen groups of more than 10 individuals in the same area, exclusively during the dry season.

The interviewees mentioned 38 different species of semi-aquatic and aquatic plants consumed by T. inunguis (Figure 2, Table S2), usually identified by direct observations or evidence of consumption in riverside and floating vegetation. The most mentioned plants were "membeca" grass (Paspalum repens and P. fasciculatum) (\%M=19.86), "canarana" grass (Echinochloa polystachia) $(\% \mathrm{M}=12.98)$ and "mureru” (Eichhornia crassipes or E. azurea) (\%M=9.09).

According to the interviewer's perception, the hunting of manatees is still occurring. Manatee poaching is considered an activity for men, and is performed only by young males. Fourteen of those interviewed (18.92\%) stated that in the past they have hunted manatees and eight $(10.81 \%)$ are still involved in hunting activities. Six people $(8.11 \%)$ whom admitted to have hunted manatees in the past, stopped poaching because they were too old to perform the hunting, or to avoid environmental enforcement actions.
Several fishermen described the procedures and tools used to hunt and kill manatees. The most common instrument used is the harpoon ("arpão"), consisting of a double tipped, $6-15 \mathrm{~cm}$ long metallic arrow, fixed to the end of the almost $3 \mathrm{~m}$ long wood shaft with $5 \mathrm{~cm}$ in diameter. The harpoon is coupled at end of the shaft ("haste"), which is usually made of hard wood of "pau d'arc" (Tabebuia impetiginosa), "preciosa" (Terminalia amazonia) or "paracuuba" (Dimorphandra macrostachya). The harpoon is attached to a 20 to $50 \mathrm{~m}$ length of rope made from cotton or nylon. The rope connects the harpoon to a floating object (that provides resistance and serves as a buoy at the surface), or directly to the canoe. The buoy serves to locate the manatee and restrain its movement once it has been harpooned, and is usually made from "mulungó" (Erythrina vellutina), wood or any other buoyant material. Another important tool used during the poaching process is the "tornos", which are conical pieces of wood used as plugs to block the manatee's nostrils and therefore kill the animal by asphyxiation. The hunter may also use a stick to hit the head and nostrils of the animal, or even a machete to cause bleeding.

The poaching occurs when the hunter finds evidences of manatee presence in the area; which is usually only

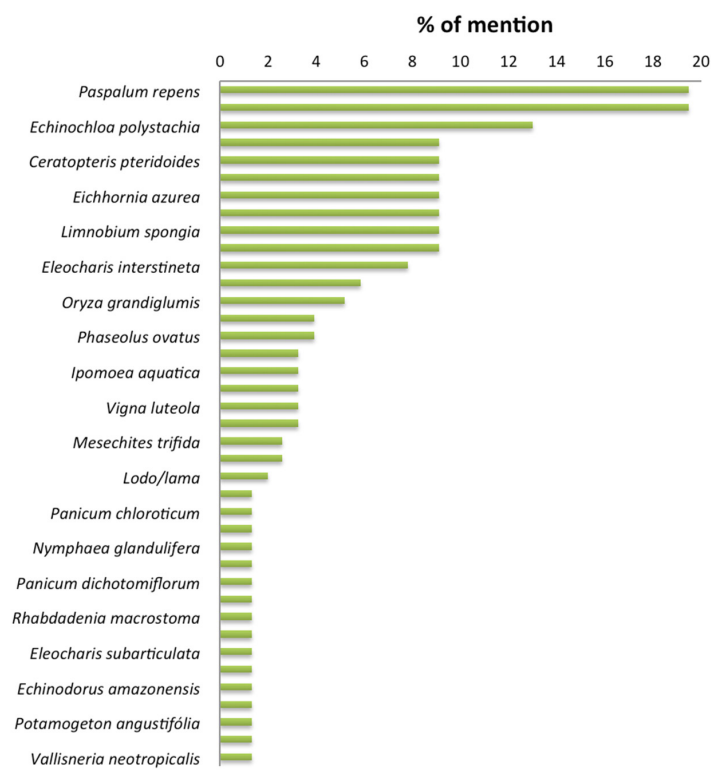

Figure 2. Plant species consumed by Trichechus inunguis, according to interviews in the Urucu Region.

Table 1. Ethno-categories of Trichechus inunguis recognized by the local people in Urucu region.

\begin{tabular}{lcccc}
\hline \multicolumn{1}{c}{ Ethno-category } & Length $(\mathbf{c m})$ & Size & Social Behavior & \% of Mention \\
\hline Camuti & $<220$ & Small & Gregarious (3-4 ind.) & 27,27 \\
Barriga Branca or Regular & $220-280$ & Medium & Solitary or in pairs & 22,73 \\
Carapanauba & $280-300$ & Medium & Solitary or in pairs & 18,18 \\
Azeite, Poaca, Banha & $>360$ & Large & Solitary or in pairs & 31,82 \\
\hline
\end{tabular}


once a year. Typically, the fisherman stays in his canoe, nearby previously identified manatee feeding areas (or "boiadouros") very quietly. The fisherman waits until the manatee is feeding or rising to the surface to breathe before he strikes. After been harpooned, the manatee usually fights for a while and begins to get tire due to the buoy attached to the harpoon. Once the animal is exhausted, the fisherman pulls the animal closer to the canoe. As soon as the animal reaches the surface, he covers the manatee's nostrils with the "tornos" to prevent it from breathing. When dead, the fishermen then partially floods the canoe to lower it in the water to help boarding the animal. He then returns to the shore to treat the skin and to prepare the meat.

A total of 20 manatees were reported captured between 2004 and 2007 (Figure 3A). Of them, 29.4\% were females and $17.6 \%$ were males. However, in most cases (56.0\%) it was not possible to obtain information about the sex, as this was not a concern for the fisherman. The Lake Coari was the area with the highest incidence of manatee deaths, with 11 animals captured. The remainder of the cases occurred in River Urucu $(n=4)$ and Lake Urucu $(n=2)$. Although manatees are reported in Lake Aruã, there were no reports of killing for that area.

Amongst the documented cases, 14 manatees (70\%) were harpooned and six (30\%) were caught in fishing nets (Figure 3B). Residents considered all the entangled
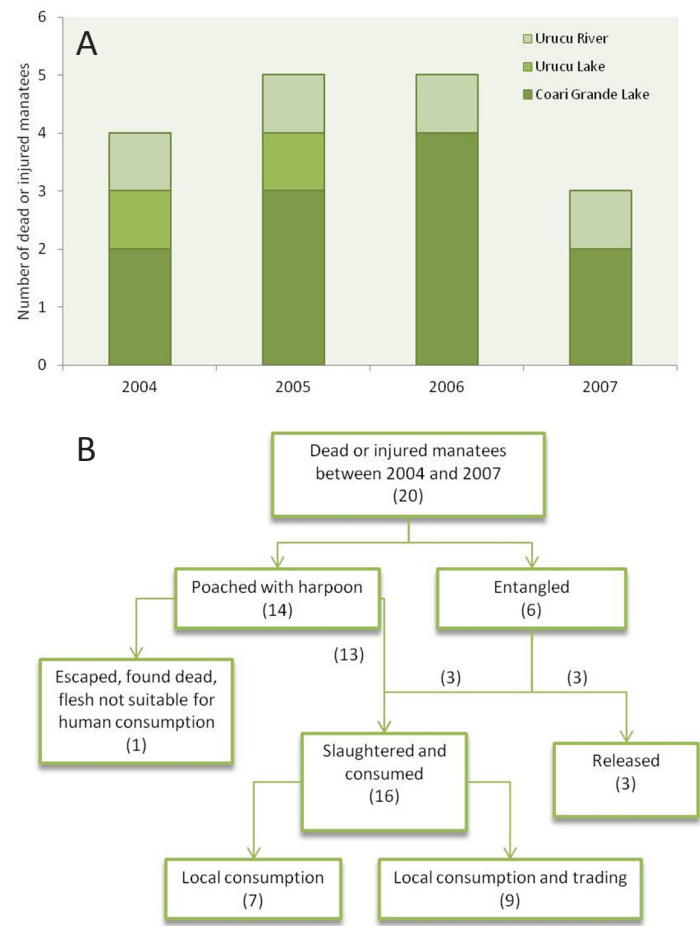

Figure 3. A) Number of cases of entagled or poached manatees Trichechus inunguis in Urucu region between 2004 and 2007. No cases of mortality were reported in Aruã and Coari Lakes. B) Use and trade of manatees in the study area. The number of individuals is in parenthesis. animals young, and three of them were released after capture. Sixteen of the slaughtered manatees were used for human consumption. One animal was harpooned but lost by the fisherman after the spear broke. The animal was found dead two days later, but the meat was no longer considered suitable for human consumption. Among the dead animals, seven (43.75\%) were destined exclusively for feeding the family of the fisherman or the community, without any kind of trade. Nine (56.25\%) were partly used for feeding the family, with part of the meat sold in the nearby communities. The meat market takes place mainly in Coari City. Once it is traded, the meat is prepared either salted, or in the traditional "mixira" (fried manatee meat preserved in its own fat). In Coari City, a kilo of mixira ranges in price from 1 to 2.5 USD while salted meat ranges 5-10 USD. Meat traffickers normally have key clients, which allow discrete trading of the product.

Half of the respondents believed that the manatee population is in decline. They also believed that the high mortality of manatees in the drought of 1963 has not yet been recovered. $35 \%$ of residents said that the manatee population has increased and $15 \%$ of respondents stated that the population is stable.

\section{Discussion}

\section{Distribution and seasonality}

It is broadly assumed that Trichechus inunguis is distributed throughout the Amazon Basin (Rosas 1994). However, the Amazon Region is a large extension of flooded plains with many suitable habitats for the species, and knowing the distribution on a smaller scale will be useful in developing consistent management plans at a local level. According to our results, the Amazonian manatee is a well-known species in the Urucu region, occurring in the main water-bodies of the system.

The seasonality of manatee hunting seems to be clear as well, and may follow seasonal variations of manatee's habitat use. Manatees are more often detected during the low and high water season; and less in raising and receding water seasons and as a consequence, the mortality is also higher in low and high water seasons. During low water season, manatees are restricted to deeper portions of water known as "poços". The local people also use those areas to fish, and therefore the probability of encounters between manatees and humans is higher. During the high water season manatees forage is more abundant in the lakes (Arraut et al. 2009), and feeding tracks of manatees are frequently observed, especially in the marginal communities of grasses. Manatee hunters explained that they use the evidence of feeding to detect and poach the manatees. The seasonality of manatee hunting has been also reported for Trichechus manatus inhabiting in Orinoco floodplains (Castelblanco-Martínez et al. 2009). 
Seasonal migrations have been well documented in other Sirenians: the Florida manatee Trichechus manatus latirostris (Deutsch et al. 2003) and the dugong Dugong dugon (Sheppard et al. 2006); and suggested in Antillean manatees T. m. manatus (Self-Sullivan et al. 2003, CastelblancoMartínez et al. 2013). The ecological processes that drive migration often seem to be related to habitat variability. A telemetry study showed that Amazonian manatees are subject to challenging habitat conditions during part of the year, and that they will migrate to areas that offers them the most suitable conditions under the difficult circumstances (Arraut et al. 2009).

\section{Morphology and behavior}

Fishermen believe that there are one to four "types" of Amazonian manatees, which we had listed here as ethnocategories. This is an extended belief in several areas where the species lives, for example in the Madeira River Basin, AM (Castelblanco-Martínez et al. 2007). However, studies carried out through molecular phylogeography, including samples of manatee from six different locations in the Amazon, did not detect significant genetic differences to support the existence of different Amazonian manatee species (Cantanhede et al. 2005). Fishermen classify types of manatees on the basis of the intra-specific diversity of the population, including individual variations, different age classes, etc.

Amazonian manatees feed on a wide variety of aquatic and semi-aquatic plant species (Best 1981; Colares \& Colares 2002).

According to Guterres et al. (2008) a total of 69 species of plants are potential food for Trichechus inunguis. Based on the interviews and plant collection, we identified 38 species that are potentially part of the Amazonian manatee diet in Urucú area. Thirty-six of them (95\%) have been yet reported in the scientific literature (Best 1981; Best \& Teixeira 1982; Colares 1990; Colares \& Colares 1992, 2002; Guterres et al. 2008), showing the confidence of the information obtained by the interviews. The species most mentioned by the fishermen corresponded to grasses. This concurs with the findings in stomach contents in which the Family Graminaeae represented $96 \%$ of ingested plants (Colares 1990). The most consumed species of plants by Amazonian manatees were Paspalum repens, Echinochloa polystachya and Eichhornia crassipes. In despite of the huge aquatic and semi-aquatic plant diversity of the Amazon region, it is likely that grasses have the most important role on the manatee feeding in the study area. It is important to note, however, that signs of feeding are more easily detected in grasses that in many other plant species (for instance, in fruits, or floating and submerse plants). Unfortunately, diet determination by microscopic analyses of feces or stomach contents does not allow the determination of the relevance of each item, since each plant undergoes a particular digestive process depending on its physical and chemical features (Fitzgerald \& Waddington 1979). Therefore, we cannot say with exactitude the relative importance of food items in the Amazonian manatee diet. More research is required in this regard.

\section{Manatee hunting and conservation}

The numbers of killed manatees reported by the fishermen does not necessarily represent the true mortality rate, since information could be omitted, forgotten, or duplicated. However, it seems to be clear that subsistence and commercial hunting are the main direct impacts on the populations of T. inunguis in the study area. Similar situations were reported to other areas of Amazonian manatee distribution (Rosas 1991) where the major threat is poaching with harpoon, although incidental captures in fishing nets could contribute a significant number of dead individuals per year. Previous reports have noted that calves and young individuals are more susceptible to be entangled (Rosas 1994).

Manatee hunting requires intellectual and physical qualities by the fisherman; and a deep knowledge on the habitat and manatee behavior. The techniques and gear used in fishing for manatees in the sample area of this study do not differ from other areas of the Amazon basin. The Lake Coari area has the most cases of hunting, and deserves special consideration. It is interesting to notice that cases of hunting where reported in all visited areas excepting in Aruã Lake. This small lake, however, present reports of manatee sightings, faeces and feeding tracks.

\section{Final Considerations}

According to the local people, manatee's poaching strategy, as many other skills and perceptions in Amazon, is a tradition taught from father to son. Therefore, the information obtained here not merely reflects the personal experiences or perceptions of those interviewed, but also the knowledge and traditions passing on from generation to generation. Although individual interviews contribute in-depth data, the assumption that words are accurate indicators of participants' inner experiences may be problematic. Interviewees may choose to hide certain information because they are afraid of law punishment, or alternatively, exaggerate or invent information to impress the interviewer. However, the obtained information is a relevant starting point to develop a better design of projects in conjunction with the local community.

For thousands of years, indigenous people around the world have used knowledge of their local environment to self-sustain and to maintain their cultural identity (Johnson 1992). In recent years, the value of traditional environmental knowledge has been recognized as a valuable source of ecological information. In the case of the Amazonian manatee, it includes not only a vast reservoir of information regarding the behavior and ecology of the species, but maybe the existence of effective indigenous strategies for ensuring 
the sustainable use of local natural resources. Additional scientific research is needed to assess the impact of the manatee hunting on the local population of manatees. We suggest that further research efforts for the Amazonian manatee in the Urucu region should be coupled with a strong and clear participation of the human population, with the goal of applying TEK in effective conservation strategies.

\section{Acknowledgments}

This project was funded by Fundação Boticário de Proteção a Natureza and PETROBRAS. The authors wish to give special thanks to the riverside communities located in the area of influence of Urucu for their hospitality and collaboration with this research. Thanks are due to Marcia Munick Mendes Cabral for her valuable help in field excursions. We acknowledge Rafael Loyola, Claudio Padia, Stuart Fulton, and Mario Rivera-Chavarría for reviewing the grammar and helpful comments on the manuscript.

\section{References}

Arraut EM et al., 2009. The Lesser Of Two Evils: Seasonal Migrations Of Amazonian Manatees In The Western Amazon. Journal Of Zoology (London), 280:247-256. http:// dx.doi.org/10.1111/j.1469-7998.2009.00655.x

Begossi A et al., 1999. Uses Of Fish And Game By Inhabitants Of An Extractive Reserve (Upper Juruá, Acre, Brazil). Environment, Development And Sustainability, 1:73-93. http://dx.doi.org/10.1023/a:1010075315060

Best RC, 1981. Foods And Feeding Habits Of Wild And Captive Sirenia. Mammal Review, 11:3-29. http://dx.doi. org/10.1111/j.1365-2907.1981.tb00243.x

Best RC \& Teixeira DM., 1982. Notas Sobre A Distribuição E "Status" Aparentes Dos Peixes-Bois (Mammalia: Sirenia) Nas Costas Amapaenses Brasileiras. Fbcn. P. 41-47.

Cantanhede AM et al., 2005. Phylogeography And Population Genetics Of The Endangered Amazonian Manatee, Trichechus inunguis Natterer, 1883 (Mammalia, Sirenia). Molecular Ecology, 14:401-413. http://dx.doi. org/10.1111/j.1365-294x.2004.02413.x

Castelblanco-Martínez DN et al., 2009. Seasonality of habitat use, mortality and reproduction of the vulnerable antillean manatee Trichechus manatus manatus in the Orinoco River, Colombia: implications for conservation. Oryx, 43:235-242. http://dx.doi.org/10.1017/S0030605307000944

Castelblanco-Martínez DN et al., 2007. Mamíferos Aquáticos. Capítulo 14. In: Rapp Py-Daniel L et al. (Eds.). Biodiversidade Do Médio Madeira: Bases Científicas Para Propostas De Conservação. Manaus: Probio/Mma. p. 225-238.

Castelblanco-Martínez DN et al., 2013. Movement Patterns Of Antillean Manatees In Chetumal Bay (Mexico) And Coastal Belize: A Challenge For Regional Conservation. Marine Mammal Science, 29:166-182. http://dx.doi. $\operatorname{org} / 10.1111 / j .1748-7692.2012 .00602 . x$
Colares IG, 1990. Hábitos Alimentares Do Peixe-Boi Da Amazônia (Trichechus inunguis, Mammalia: Sirenia). Inpa/Fua.

Colares IG \& Colares EP, 1992. Preferência Alimentar Do Peixe-Boi Da Amazônia Em Cativeiro. Revista Peixe Boi Ibama, 26-32. http://dx.doi.org/10.1590/ s1516-89132002000100011

Colares IG \& Colares EP, 2002. Food Plants Eaten By Amazonian Manatees (Trichechus inunguis, Mammalia: Sirenia). Brazilian Archives Of Biology And Technology, 45:67-72.

Costa RC \& Nunez CV, 2011. Ethno-Knowledge And Bioproducts Market In Manaus-Am. Emiratos Journal Of Food And Agriculture, 23:237-242.

Deutsch CJ et al., 2003. Seasonal movements, migratory behavior and site fidelity of West Indian manatees along the Atlantic Coast of the United States. Wildlife Monographs, 151:1-77.

Fitzgerald AE \& Waddington DC, 1979. Comparison Of Two Methods Of Fecal Analysis Of Herbivore Diet. The Journal Of Wildlife Management, 43: 468-473. http://dx.doi. org/10.2307/3800357

Guterres MG et al., 2008. Anatomia E Morfologia De Plantas Aquáticas Da Amazônia: Utilizadas Como Potencial Alimento Por Peixe-Boi Amazônico. Idsm.

Harris M, 1998. The Rhythm Of Life On The Amazon Floodplain: Seasonality And Sociality In A Riverine Village. The Journal Of The Royal Anthropological Institute, 4:65-82. http://dx.doi. org/10.2307/3034428

Johnson M, 1992. Research On Traditional Environmental Knowledge: Itsdevelopment And Its Role. In: Johnson M (Ed.). Lore: Capturing Traditional Environmental Knowledge.

Lambert SD \& Loiselle CG, 2008. Combining Individual Interviews And Focus Groups To Enhance Data Richness. Journal Of Advanced Nursing, 62:228-237. http://dx.doi. org/10.1111/j.1365-2648.2007.04559.x

Marmontel M, 2008. Trichechus inunguis. version 2012.2. IUCN Red List Of Threatened Species.

Rosas FCW, 1991. Peixe-Boi Da Amazônia Trichechus inunguis (Natterer, 1883). In: Capozzo Hl \& Junin M. (Eds.). Estado De Conservación De Los Mamíferos Marinos Del Atlántico Sudoccidental. Programa De Mares Regionales Del Pnuma. P. 178-181.

Rosas FCW, 1994. Biology, Conservation And Status Of The Amazonian Manatee Trichechus inunguis. Mammal Review, 24:49-59. http://dx.doi.org/10.1111/j.1365-2907.1994. tb00134.x

Self-Sullivan C et al., 2003. Seasonal occurrence of male Antillean manatees (Trichechus manatus manatus) on the Belize Barrier Reef. Aquatic Mammals, 29:342-354. http:// dx.doi.org/10.1578/01675420360736514

Sheppard JK et al., 2006. Movement Heterogeneity Of Dugongs, Dugong dugon (Muller), Over Large Spatial Scales. Journal Of Experimental Marine Biology And Ecology, 334:64-83. http://dx.doi.org/10.1016/j.jembe.2006.01.011 